\title{
Evidence for persistent seed banks in dwarf eelgrass Zostera noltii in the German Wadden Sea
}

\author{
Andreas M. Zipperle ${ }^{1, *}$, James A. Coyer ${ }^{1}$, Karsten Reise ${ }^{2}$, Wytze T. Stam ${ }^{1}$, \\ Jeanine L. Olsen ${ }^{1}$ \\ ${ }^{1}$ Department of Marine Benthic Ecology \& Evolution, Centre for Ecological and Evolutionary Studies, Biological Centre, \\ University of Groningen, Kerklaan 30, PO Box 14, 9750 AA Haren, The Netherlands \\ ${ }^{2}$ Alfred Wegener Institute for Polar and Marine Research, Wadden Sea Station Sylt, 25992 List, Germany
}

\begin{abstract}
The intertidal dwarf eelgrass Zostera noltii is a dominant species in the Dutch and German Wadden Sea. Although numerous studies of its reproductive ecology have been conducted, few have examined the importance of seeds and seed banks for meadow maintenance. We investigated the contribution of a seed bank (size, genetic potential and persistence) to annual recruitment of dwarf eelgrass in the German Wadden Sea using temporal sampling of seeds from the sediment and genetic assignment tests of seedlings to populations of adult shoots from previous years. Annual sediment seed density (SD) was $487.5 \mathrm{~m}^{-2}$ (269.4) and $367.3 \mathrm{~m}^{-2}$ (95.5) in 2004 and 2005, respectively, and distribution of seeds in the sediment was highly aggregated. The proportion of over-wintering seeds that germinated under laboratory conditions was 16 to $25 \%$, and field-germination revealed a $12 \%$ survival to the seedling stage. Nearly $20 \%$ of all shoots present in May 2004 were seedlings. Using 9 microsatellite loci, seedlings sampled in 2004, 2005 and 2006 were compared with adults sampled in 2002, 2003 and 2004; results revealed that 7 to $33 \%$ of seedlings could be assigned to the local adult population in current or previous years. Although new recruitment plays an important role in the maintenance of these meadows, considerable new recruitment comes from within the meadow itself. Seeds are viable for at least 3 yr, thereby forming a relatively short-term, but persistent, seed bank.
\end{abstract}

KEY WORDS: Seed bank · Seagrass $\cdot$ Persistence $\cdot$ Germination $\cdot$ Zostera noltii $\cdot$ German Wadden Sea

\section{INTRODUCTION}

The contribution of annual and sexual recruitment from seeds relative to perennial and asexual propagation by rhizomes varies widely in eelgrass Zostera sp. Consequently, meadow or patch composition may range from nearly every shoot arising from a separate seed (Coyer et al. 2004a, Olsen et al. 2004) to a single, long-lived clone with little, if any, recruitment (Reusch et al. 1999). Factors affecting this variation include patch isolation (Reusch 2003), poor dispersal (Hämmerli \& Reusch 2003a), intraspecific density-dependent competitive interactions (Hämmerli \& Reusch 2003b, Reusch 2006), low seed production (Loqués et al. 1990, Alexandre et al. 2006), local seed predation
(Fishman \& Orth 1996) and the absence of a seed bank (Hootsmans et al. 1987, Harrison 1993).

Viable seeds in the sediment constitute an agestructured seed bank of which 3 types are distinguished: transient (persisting for $<1 \mathrm{yr}$ ), short-term (from 1 to $5 \mathrm{yr}$ ) and long-term ( $>5 \mathrm{yr}$ ) (Thompson et al. 1997). As seed banks provide a genetic reservoir for changing environmental conditions, subsequent recruitment can strongly influence population structure and genotypic diversity, especially for clonal plants (Eriksson 1989, Morris et al. 2002, Koch et al. 2003, Barrett et al. 2005, Reusch et al. 2005, Reusch 2006, Reusch \& Hughes 2006),

After the near total loss of subtidal eelgrass Zostera marina meadows to a wasting disease in the early 


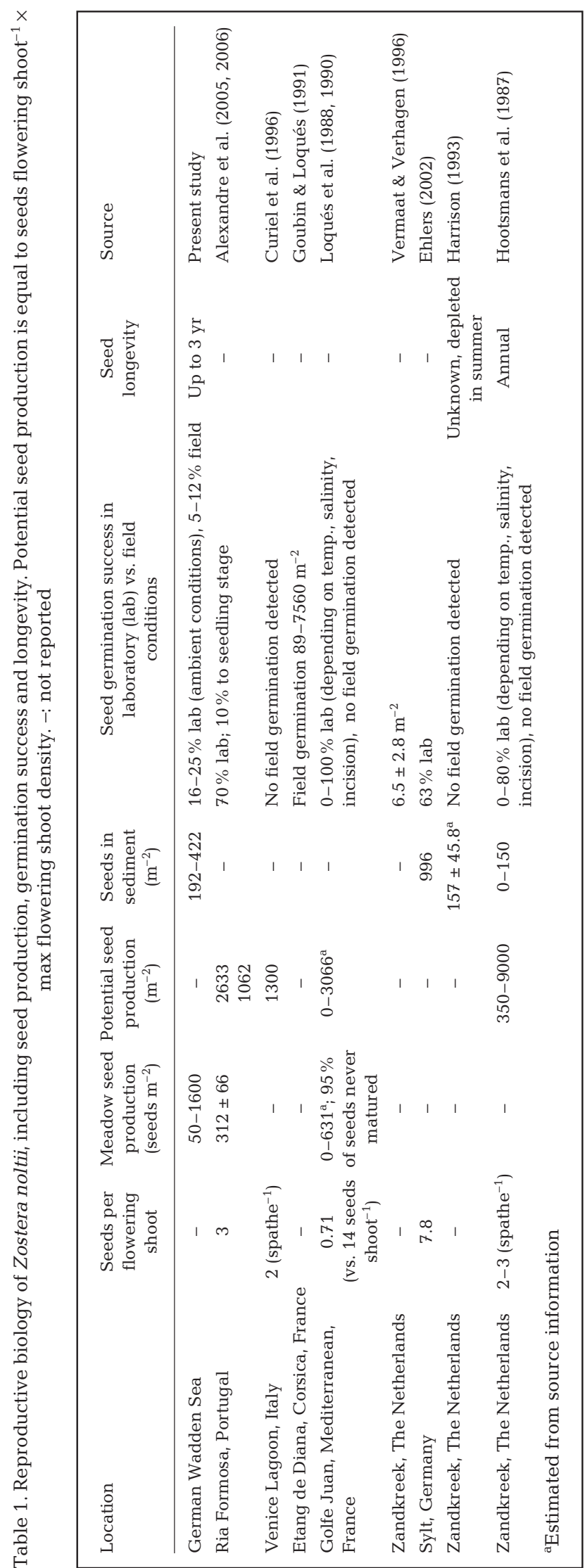

1930s, dwarf eelgrass $Z$. noltii has emerged as the primary seagrass species inhabiting the Wadden Sea, particularly in the northern regions (Reise \& Kohlus 2008). Dwarf eelgrass is usually confined to the upper intertidal zone of sheltered sandy and/or muddy European coastlines, but sometimes it is found in the shallow subtidal zone (den Hartog 1970).

Like most seagrasses, Zostera noltii propagates vegetatively by rhizomatous growth and sexually through seeds. It is a protogynous hermaphrodite, with 4 to 6 female and 4 to 6 male flowers grouped in a single floral unit (spathe). Within a single spathe, flowers mature first to avoid self-fertilization, although asynchronous maturation of several spathes from the same genet (sensu Harper 1977) may result in self-fertilization (geitonogamous selfing) (Reusch 2001). Fertilization relies on sub-aquatic pollen transport to receptive stigmas. Mature seeds are negatively buoyant and drop to the sediment surface after release. While some seeds enter the sediment, the vast majority are dispersed away, either as bare seeds or in the spathes of floating leaf wrack (Loques et al. 1988). Nevertheless, seeds that are buried may or may not provide a seed bank and, likewise, seeds that are transported may or may not be lost.

Several studies have directly examined the reproductive ecology of Zostera noltii including flowering, seed production, seed density (sediments), seed viability and germination (Table 1). Persistence of seed banks, however, is typically inferred from laboratory studies of seed germination following temporal storage of seeds in seawater under dark and cold conditions (McMillan 1991, Orth et al. 2000) and/or from the presence of seeds in sediment cores sampled in the field (Hootsmans et al. 1987, Harrison 1993). While all of these studies have demonstrated potential seed longevity, none have been able to establish actual longevity. In the present study, we use temporal sampling and genetic assignment tests to determine (1) the size and the genetic potential of the seed bank, (2) seed bank persistence or seed viability over time and (3) the year-to-year contribution of the seed bank to recruitment within $Z$. noltii meadows.

\section{MATERIALS AND METHODS}

Study site. We studied a Zostera noltii meadow (ca. $0.125 \mathrm{~km}^{2}$ ) in the shallow bay of Königshafen $\left(55^{\circ} 2^{\prime} 50^{\prime} \mathrm{N}, 008^{\circ} 25^{\prime} 50^{\prime} \mathrm{E}\right)$ off the Island of Sylt in the German Wadden Sea (Fig. 1). Tides are semidiurnal (mean tidal range $=1.8 \mathrm{~m}$ ), mean annual water temperature is $9^{\circ} \mathrm{C}$ (seasonally varying between -2 and $19^{\circ} \mathrm{C}$ ) and salinity varies from 28 to 32 psu (for further description see Gätje \& Reise 1998). The meadow is 
exposed for 6 to $8 \mathrm{~h}$ during each low tide and water depth during high tide is typically $0.5 \mathrm{~m}$. A permanent $10 \times 10 \mathrm{~m}$ plot (ca. $0.1 \%$ of the meadow) was established near the center of the meadow in April 2002. Corners were marked with metal stakes driven com-
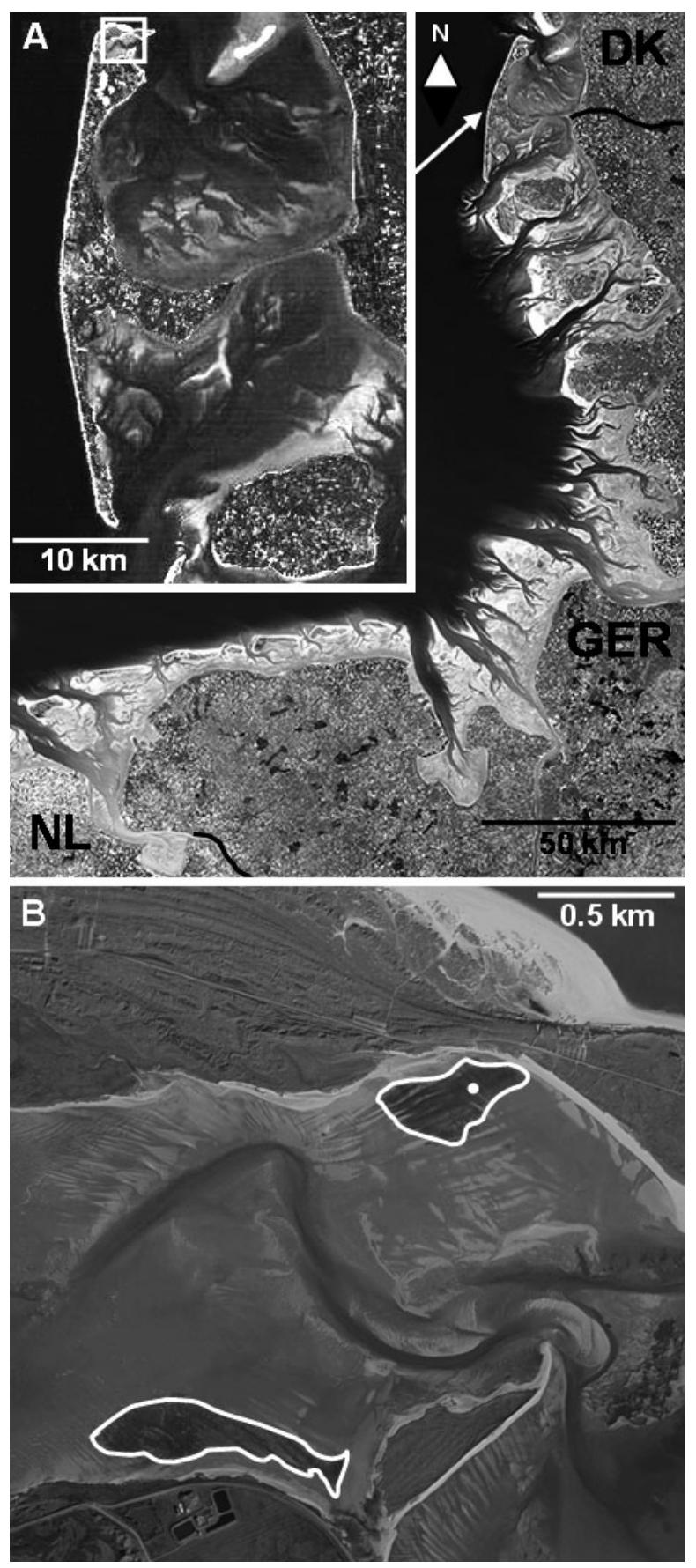

Fig. 1. Study area. (A) German Wadden Sea. Inset: the shallow bay of Königshafen (small white square) located off the Island of Sylt. DK: Denmark; GER: Germany; NL: The Netherlands. (B) Zostera noltii meadows in Königshafen (outlined in white) and plot location (white dot) pletely into the sediment to which a small piece of nylon line was attached and lay exposed on the surface. At each sampling period, stakes were relocated (using photographs, landmarks and nylon line) and connected with $10 \mathrm{~m}$ transect tapes. A preliminary ANOVA for sediment seed density over scales of centimetres to kilometres revealed the least variation at the $1 \times 1 \mathrm{~m}$ level, thus the $10 \times 10 \mathrm{~m}$ plot is an appropriate size (A. M. Zipperle unpubl. data)

Seed census. Seed density was assessed on a monthly basis from April to October 2004 and 2005. During each sampling period, 40 cores $(7.5 \mathrm{~cm}$ diam. $\left[0.004 \mathrm{~m}^{2}\right], 10 \mathrm{~cm}$ deep) were collected at random from within the $10 \times 10 \mathrm{~m}$ plot. In the laboratory, samples were sieved through $500 \mu \mathrm{m}$ mesh (Zostera noltii seed size $=1$ to $2 \mathrm{~mm}$ ) using ambient seawater. The retained sediment was oven-dried at $50^{\circ} \mathrm{C}$ for $48 \mathrm{~h}$ and then examined under a dissecting microscope for intact seeds. Seeds were collected from the plot (as opposed to throughout the bed) for future spatial and/or genetic matching with seedlings and adult shoots within the plot. Coring-induced disturbance was minimal as the cumulative area cored during 7 mo was only $1 \%$ of the plot.

Seed germination. Seeds persisting throughout winter 2004-2005 (corresponding to 2004 and/or earlier seed sets) were collected in April 2005 from the Königshafen meadow ( $\mathrm{n}=64$ ), as well as another meadow $10 \mathrm{~km}$ south $(\mathrm{n}=36)$. Seeds were extracted directly from wet sediment cores for both populations. Five seeds were placed in each of 13 (Königshafen) and 6 (southern population) PVC Petri dishes and covered with $1 \mathrm{~cm}$ of sieved sediment collected adjacent to the seed collections. Petri dishes were marked and placed randomly in a flow-through tank with ambient seawater at a depth of $0.5 \mathrm{~m}$ and a $12 \mathrm{~h}$ light:12 h dark light cycle using white fluorescent light tubes $(20$ umol $\mathrm{m}^{-2} \mathrm{~s}^{-1}$ ). Germination was evaluated on a daily basis for $6 \mathrm{wk}$ and considered complete when the green cotyledon was visible. After germination, seedlings were removed and discarded. The experiment was concluded after $6 \mathrm{wk}$ and all seeds that failed to germinate were discarded.

Field germination and survival to the seedling stage was estimated by the average seedling density and average seed bank size during the germination period (April to June 2004). Germination depth of 100 seedlings was measured in the Königshafen meadow to determine the optimal burial depth. Seedlings were distinguished from overwintering shoots by appearance of a caulicle and a green cotyledon (Dawson 1966); the attached seed and seed coat were revealed after excavation. The cotyledon was cut at the sediment surface level and the seedling was excavated. Germination depth was defined as the distance 
between the cut edge of the cotyledon and the stillattached seed.

Meadow phenology. Densities of vegetative and flowering shoots were monitored on a monthly basis throughout the growing season of April to October 2004. Shoots were counted in each of ten $0.25 \mathrm{~m}^{2}$ quadrats placed randomly within the $10 \times 10 \mathrm{~m}$ plot. During spring 2004, an additional 10 random quadrats were examined for seedlings on a biweekly basis. With loss of the caulicle (usually 4 wk after seed germination), seedlings could no longer be distinguished from adult and newly produced vegetative shoots.

Sampling of adults and seedlings for genotyping. All tissue samples and seedlings were collected by subdividing the $10 \times 10 \mathrm{~m}$ into $1 \mathrm{~m}^{2}$ quadrats (Coyer et al. 2004a). Sampled seedlings were easily distinguished from newly produced ramets as discussed above. Leaf tissue was removed from one adult shoot at the center of each $1 \mathrm{~m}^{2}$ quadrat (maximum of 100 samples) in spring (May to June) and autumn (September) from 2002 to 2004 . If no shoot was present within a $10 \mathrm{~cm}$ radius around the center of the quadrat, no sample was collected. Intact seedlings were collected in May 2005 ( $\mathrm{n}=179)$ and 2006 ( $\mathrm{n}=40)$. No samples were collected from November to April because little biomass was present and no flowering or seed germination occurred. All leaf tissues and seedlings were stored in silica crystals prior to DNA extraction.

DNA extraction, microsatellite amplification and genotyping. Whole seedlings and $5 \mathrm{mg}$ of silica-dried leaf tissue from adult shoots were pulverized using a Retsch Mixer Mill MM 301 (Qiagen). DNA was extracted following Elphinstone et al. (2003). Nine microsatellite loci (Coyer et al. 2004b) were amplified using multiplex PCR (Table 2) as follows: $2 \mathrm{mM} \mathrm{MgCl}_{2}$, $0.2 \mathrm{mM}$ dNTPs, 0.5 U Taq (Promega), $0.01 \%$ bovine serum albumin, reaction buffer $(10 \mathrm{mM}$ Tris $\mathrm{Hcl}$, $50 \mathrm{mM} \mathrm{KCl}, 0.1 \%$ Triton X-100) in a total volume of $20 \mu \mathrm{l}$ per reaction. PCR reaction conditions were the

Table 2. Multiplexing conditions for microsatellite loci

\begin{tabular}{|cccc|}
\hline Tri-plex & $\begin{array}{c}\text { Locus } \\
\text { (GenBank } \\
\text { accession no.) }\end{array}$ & $\begin{array}{c}\text { Primer } \\
\text { concentration } \\
(\mu \mathrm{M})\end{array}$ & $\begin{array}{c}\text { Fluorescent } \\
\text { label } \\
\text { (forward primer) }\end{array}$ \\
\hline \multirow{2}{*}{$\begin{array}{c}\text { ZnB1 (AY566799) } \\
\text { ZnH10 (AY566807) }\end{array}$} & 0.1 & NED \\
& ZnB3 (AY566800) & 0.24 & 6-FAM \\
& ZnB8 (AY566801) & 0.72 & HEX \\
& ZnH8 (AY566806) & 0.1 & 6-FAM \\
& ZnD6 (AY566802) & 0.24 & NED \\
& ZnE7 (AY566803) & 0.2 & 6-FAM \\
& ZnF8 (AY566804) & 0.08 & HEX \\
& ZnF11 (AY566805) & 0.12 & 6-FAM \\
\hline
\end{tabular}

same for each primer triplet: initial denaturation $3 \mathrm{~min}$ at $94^{\circ} \mathrm{C}$ followed by 35 cycles consisting of $40 \mathrm{~s}$ at $94^{\circ} \mathrm{C}$, $40 \mathrm{~s}$ at $57.5^{\circ} \mathrm{C}$ and $40 \mathrm{~s}$ at $72^{\circ} \mathrm{C}$ with a final extension step of $10 \mathrm{~min}$ at $72^{\circ} \mathrm{C}$. Each multiplexed primer triplet was visualized by gel electrophoresis on an ABI 377 gene analyzer (Applied Biosystems). Alleles were scored against an internal lane standard (ROX 350, Applied Biosystems) applying the GENSCAN software (Applied Biosystems).

Data analysis. Individual ramets (shoots) can share the same multi-locus genotype (MLG) either by chance or because they belong to the same genet (clone). To avoid false assignment of adult shoots to clones, probabilities of identity by chance $\left(\mathrm{P}_{\text {sex }}\right)$ were calculated for shoots sharing the same MLG using GenClone 2.0 (Arnaud-Haond \& Belkhir 2007). Duplicate MLGs were considered only once in subsequent analyses.

Assignment tests were conducted using the software GeneClass2 (Piry et al. 2004), which uses a Bayesian approach (Rannala \& Mountain 1997) to determine the likelihood of assignment of seedlings to adults. Because any given adult clone can persist from year to year, it is possible that a seedling might be assigned to more than one year class. To minimize this possibility, we accepted a particular year class as a source for a seedling only if the assignment likelihood was > $95 \%$. Our analysis should be regarded as a minimal estimate because sampling was not exhaustive and unassigned seedlings may come from year classes not included in the sampling or from locations outside of the study area.

Assignment tests utilize both allele frequency differences $\left(F_{\mathrm{ST}}\right)$ and MLGs of the seedlings and adults. Thus, where $F_{\mathrm{ST}}$ values were not significant between years $(2002,2003)$, samples were pooled. Assignment of 2006 seedlings to the 2005 adults was not feasible because a widespread and extreme heat wave in 2003 reduced population density by $>99 \%$ in subsequent years $(2004,2005)$ and too few adult shoots were available in 2005 (A. M. Zipperle et al. unpubl. data). Values presented are means \pm SD.

\section{RESULTS}

\section{Meadow phenology}

An increase in the number of vegetative and flowering shoots started in June-July, peaked in August and steadily declined to October (Fig. 2), a phenological pattern typical of other locations in the Wadden Sea (den Hartog 1970, Jacobs et al. 1983, Vermaat \& Verhagen 1996). At peak growth in July/August 2004, densities of vegetative and flowering shoots were highly variable at $2842 \pm 1373$ and $310 \pm 263 \mathrm{~m}^{-2}$, respectively. 


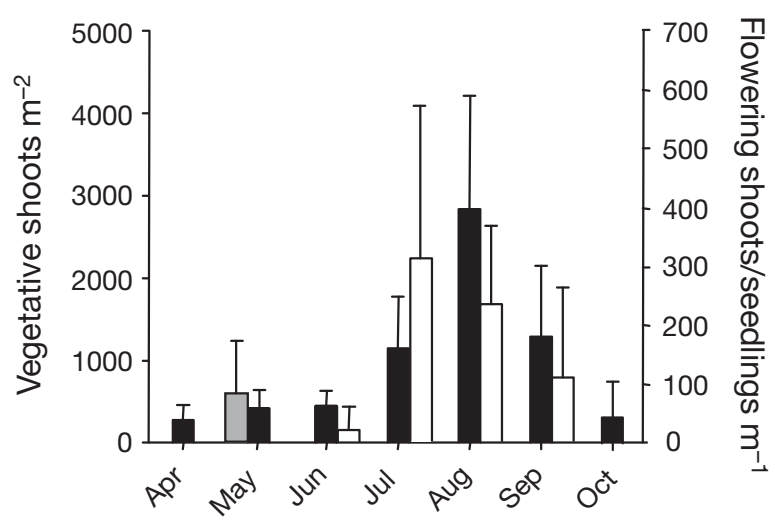

Fig. 2. Phenology of the Zostera noltii meadow in Königshafen in 2004. Density of vegetative shoots (black bars), seedlings (grey bar) and flowering shoots (white bars) is plotted by month. Means + SD are shown

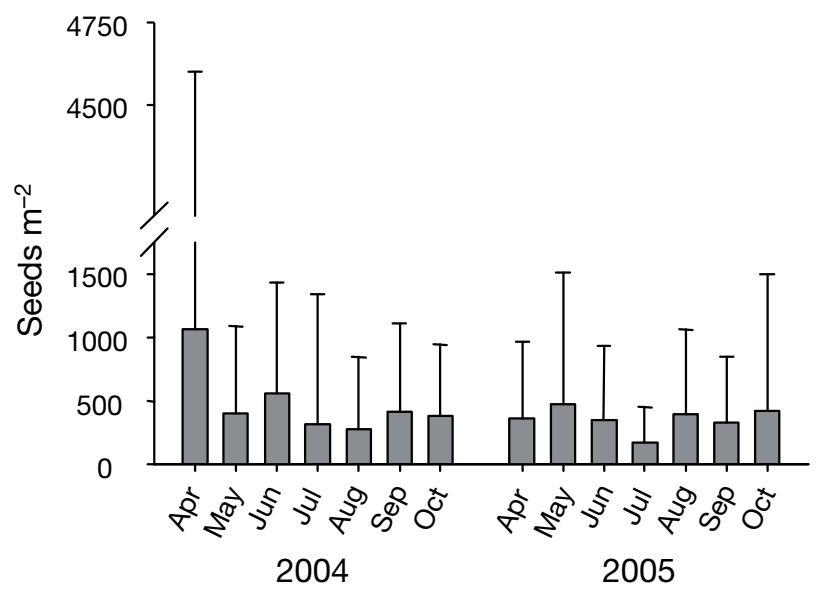

Fig. 3. Seed bank densities at the 2 study sites on Sylt from April to October 2004 and 2005. Means + SD are shown

Flowering shoots accounted for $10 \%$ of total shoot density at peak growth. The average seedling density in May 2004 was also highly variable at $83 \pm 88.8 \mathrm{~m}^{-2}$, ranging from 0 to $288 \mathrm{~m}^{-2}$. Compared to vegetative shoot density in May $\left(426 \pm 228.3 \mathrm{~m}^{-2}\right)$, seedlings represented $19.5 \%$ of shoots in the $10 \times 10 \mathrm{~m}$ plot.

\section{Seed bank and seed germination}

Seeds were present in the sediment throughout 2004 $\left(487.5 \pm 269.4 \mathrm{~m}^{-2}\right)$ and $2005\left(367.3 \pm 95.5 \mathrm{~m}^{-2}\right)$ with no discernable seasonal pattern because of the very high variances (Fig. 3). Laboratory germination of seeds collected from the overwintering seed banks showed that 16 to $25 \%$ were viable. An estimate of field germination and survival to the seedling stage was $12 \%$. Mean
Table 3. Assignment tests of Zostera noltii seedlings. Percent assignment of individual seedlings from 2005 and 2006 to the adult populations from 2002-2003 and 2004. Assignment was accepted only if a seedling was assigned with a likelihood of $>95 \%$

\begin{tabular}{|lcccc|}
\hline $\begin{array}{l}\text { Collection } \\
\text { date }\end{array}$ & $\begin{array}{c}\text { Not } \\
\text { assigned }\end{array}$ & $\begin{array}{c}\text { Assigned to } \\
\text { adults } \\
2004\end{array}$ & $\begin{array}{c}\text { Assigned to } \\
\text { pooled adults } \\
\text { 2002-2003 }\end{array}$ & $\begin{array}{c}\text { Total } \\
\text { assigned }\end{array}$ \\
\hline 2005 & 73.2 & 7.1 & 19.6 & 26.8 \\
2006 & 67.5 & 2.5 & 30 & 32.5 \\
\hline
\end{tabular}

germination depth was $4.1 \pm 0.9 \mathrm{~cm}$ in 2004 and $3.0 \pm$ $1.0 \mathrm{~cm}$ in 2005, but successful germination was observed throughout a 1 to $7 \mathrm{~cm}$ depth range. No seedlings germinated from seeds lying directly on the sediment surface.

\section{Assignment}

One in 3 seedlings was assigned to their home populations (Table 3), establishing the importance of local recruitment. Additionally, temporal assignment revealed that year-class seedlings arose from seeds originating from up to $3 \mathrm{yr}$ previously (19.6 to $30 \%$ ), thus establishing that seeds banks were not transient. Most seedlings from 2005 and 2006 were assigned to the pooled adult population of 2002-2003.

\section{DISCUSSION}

Earlier studies were unable to confirm the existence of a Zostera noltii seed bank using presence/absence data of sediment seeds or seedling emergence because (1) seeds in the sediment are not necessarily viable, (2) viable seeds do not necessarily germinate, and (3) the origin of germinated seeds is unknowable without genetic data (Hootsmans et al. 1987, Harrison 1993). Our estimates of seed density for 2004 $\left(487.5 \mathrm{~m}^{-2}\right)$ and $2005\left(357.3 \mathrm{~m}^{-2}\right)$ match well with previous studies conducted in Portugal, the French Mediterranean and the SW Netherlands (Table 1). However, previous studies were not able to assess successful recruitment in situ and methodology varied widely. In the present study, new recruitment accounted for nearly $20 \%$ of the new shoots each spring and 26.7 to $32.5 \%$ of the new seedlings originated from within the plot itself. Among these, $30 \%$ were traced to seeds from up to 3 yr earlier, suggesting that the stability and genetic diversity for the northern Wadden Sea $Z$. noltii meadows may be related to the persistent seed banks. Persistent, as opposed to transient, seed banks are bet- 
ter able to buffer the stochastic year-to-year variation in seed production, conserve genetic diversity through time and allow the regeneration of meadow-level genotypic diversity after disturbance-related mortality (Honnay et al. 2008).

The strongly negative impact of a severe heat-stress event (HSE) in the summer of 2003 reported for several seagrass populations in Europe (Mayot et al. 2005, Reusch et al. 2005) affected the Königshafen meadow as well. Losses of up to $99 \%$ in subsequent years (A. M. Zipperle et al. unpubl. data) undoubtedly reduced both seed output and the number of seeds in the seed bank in the years immediately following the HSE (2004 and 2005). Consequently, most seedlings from 2005 and 2006 were assigned to the pooled adult population of 2002-2003.

Although we have shown that nearly one third of the annual recruitment came from within the meadow, the remaining $70 \%$ originated from either outside the meadow or from seeds produced within the meadow before 2002. Zostera seeds are heavy and negatively buoyant (Loques et al. 1988, Orth et al. 1994). As direct estimates of seed dispersal suggest distances of only a few metres (Orth et al. 1994), the majority of seeds in the seed bank of our $10 \times 10 \mathrm{~m}$ plot most likely were produced in the vicinity of the plot. Nevertheless, long distance dispersal must be considered, as detached spathes and whole flowering shoots can be transported by currents, and studies at this level have demonstrated that both seed dispersal (Harwell \& Orth 2002, Erftemeijer et al. 2008, Källström et al. 2008) and gene flow (Reusch 2002, Ferber et al. 2008) occur over 10s of kilometres.

Seedling recruitment also maintains genetic and genotypic diversity (Reusch et al. 2005). As Zostera noltii has a genet lifetime of at least 4 yr (A. M. Zipperle et al. unpubl. data), a minimal annual recruitment of only $2 \%$ of the seedlings $\left(83 \mathrm{~m}^{-2}\right)$ would add 1.5 genotypes $\mathrm{m}^{-2}$ into the population.

Growth of overwintering rhizomes begins in May-June, nearly a month after the appearance of seedlings (Vermaat \& Verhagen 1996, A. M. Zipperle pers. obs.). The amount of vegetative growth is positively correlated with the number of leaf-bearing rhizomes surviving the winter (Vermaat \& Verhagen 1996). Therefore, high winter survivorship implies a more extensive amount of vegetative growth (at $68 \mathrm{~cm}$ $\mathrm{yr}^{-1}$, Marbà \& Duarte 1998) the following spring, resulting in fewer gaps in the canopy for seedling recruitment and more competition from vegetatively expanding adult plants. If regular disturbances, such as grazing waterfowl and storms, significantly open the canopy by the end of the growing season, the number of overwintering rhizomes will be lower, and seedling recruitment in the following spring should be higher. Thus, the proportion of seedlings in a given meadow is likely to vary considerably from year to year and may be more or less than the $5 \%$ suggested by Jacobs et al. (1981).

Grazing by waterfowl creates depressions or feeding pits by removing the canopy and rhizomes. If the pits are formed after seed set they can form seed traps, which will lead to a clumped distribution of seeds in the sediment (Orth et al. 1994, Luckenbach \& Orth 1999). On Sylt, dwarf eelgrass seeds accumulate in feeding pits and are buried after a few tidal cycles (Ehlers 2002). As the average depth of feeding pits is $4.5 \mathrm{~cm}$ (Nacken 1998), feeding pits provide an ideal habitat for seed germination (Churchill 1992, Moore et al. 1993) and probably account for the clumped distributions (and high variances) we observed for seeds. An experimental study that artificially created pits in autumn showed that germination the following spring was higher in experimental pits than in undisturbed controls (A. M. Zipperle et al. unpubl. data). Taken together, the average germination depth of seedlings (3 to $4 \mathrm{~cm}$ ) and the mean depth of feeding pits $(4.5 \mathrm{~cm})$ suggest that waterfowl grazing facilitates the formation of a seed bank and subsequent seedling recruitment. A similar process has been demonstrated for other seagrasses, where seeds accumulated in feeding trails of dugongs and pits caused by strong hydrodynamics (Inglis 2000).

Zostera noltii has adapted to moderate levels of disturbances in the intertidal zone by combining fast vegetative propagation with high levels of sexual reproduction. As long as intermittent disturbances do not deplete the seed bank, by either disturbing the sediment directly or reducing the meadow seed output, recovery is possible by recruitment. If, on the other hand, the canopy is severely disturbed repeatedly, seed output will decrease, the seed bank will become depleted, and import from nearby donor populations will be reduced or halted.

The present study has partially resolved the paradox of finding extremely high genetic diversity of Zostera noltii populations in the German Wadden Sea (as compared with the rest of its European distribution) given their relatively recent colonization since the last glacial retreat several thousand years ago (Coyer et al. 2004a). As $70 \%$ of annual recruitment came from outside the study meadow and/or from seeds deposited more than 3 yr earlier, much of the unexpectedly high diversity must stem from admixture from outlying areas (Ferber et al. 2008, A. M. Zipperle unpubl. data). The ability of $Z$. noltii to form short-term persistent seed banks and the seed dispersal abilities in detached flowering shoots may help to explain the increase in Z. noltii populations in the Wadden Sea in the past 3 decades (Reise \& Kohlus 2008), as well as population resilience in highly mobile intertidal soft sediments. 
Acknowledgements. We thank T. Reusch, A. Piquet and M. V. Ruggiero for field assistance and 4 anonymous reviewers for substantial comments. This research was supported by an Ubbo Emmius PhD stipend from the University of Groningen to A.M.Z.

\section{LITERATURE CITED}

Alexandre A, Santos R, Serrão E (2005) Effects of clam harvesting on sexual reproduction of the seagrass Zostera noltii. Mar Ecol Prog Ser 298:115-122

Alexandre A, Cabaço S, Santos R, Serrão EA (2006) Timing and success of reproductive stages in the seagrass Zostera noltii. Aquat Bot 85:219-223

> Arnaud-Haond S, Belkhir K (2007) GENCLONE: a computer program to analyze genotypic data, test for clonality and describe spatial clonal organization. Mol Ecol Notes 7: $15-17$

Barrett LG, He TH, Lamont BB, Krauss SL (2005) Temporal patterns of genetic variation across a 9-year-old aerial seed bank of the shrub Banksia hookeriana (Proteaceae). Mol Ecol 14:4169-4179

Churchill AC (1992) Growth characteriszics of Zostera marina seedlings under anaerobic conditions. Aquat Bot 43: 379-392

Coyer JA, Diekmann OE, Serrão EA, Procaccini G and others (2004a) Population genetics of dwarf eelgrass Zostera noltii throughout its biogeographic range. Mar Ecol Prog Ser 281:51-62

Coyer JA, Reusch TBH, Stam WT, Serrão EA, Pearson G, Procaccinis G, Olsen JL (2004b) Characterization of microsatellite loci in the dwarf eelgrass Zostera noltii (Zosteraceae) and cross-reactivity with $Z$. japonica. Mol Ecol Notes 4:497-499

Curiel D, Bellato A, Rismondo A, Marzocchi M (1996) Sexual reproduction of Zostera noltii Hornemann in the lagoon of Venice (Italy, north Adriatic). Aquat Bot 52:313-318

Dawson EY (ed) (1966) Spermatophytes, mangrove associations, salt marshes. In: Marine botany: an introduction. Holt, Rinehart \& Winston, New York

den Hartog C (1970) The seagrasses of the world. North Holland Publishing, Amsterdam

Ehlers A (2002) Positive und negative Effekte von Wasservögeln auf submerse Vegetation: zwischen Ueberweidung und Samenverbreitung. Master thesis, ChristianAlbrechts-Universität Kiel

Elphinstone MS, Hinten GN, Anderson MJ, Nock CJ (2003) An inexpensive and high-throughput procedure to extract and purify total genomic DNA for population studies. Mol Ecol Notes 3:317-320

Erftemeijer PLA, van Beek JKL, Ochieng CA, Jager Z, Los HJ (2008) Eelgrass seed dispersal via floating generative shoots in the Dutch Wadden Sea: a model approach. Mar Ecol Prog Ser 358:115-124

Eriksson O (1989) Seedling dynamics and life histories in clonal plants. Oikos 55:231-238

Ferber S, Stam WT, Olsen JL (2008) Genetic diversity and connectivity remain high in eelgrass Zostera marina populations in the Wadden Sea, despite major impacts. Mar Ecol Prog Ser 372:87-96

Fishman JR, Orth RJ (1996) Effects of predation on Zostera marina L. seed abundance. J Exp Mar Biol Ecol 198:11-26

Gätje C, Reise K (1998) Ökosystem Wattenmeer: Austausch-, Transport-, und Stoffumwandlungsprozesse. Springer, Berlin

Goubin C, Loqués F (1991) Germinating Zostera noltii Horne- mann found in the Etang de Diana, Corsica. Aquat Bot 42: $75-79$

Hämmerli A, Reusch TBH (2003a) Genetic neighbourhood of clone structures in eelgrass meadows quantified by spatial autocorrelation of microsatellite markers. Heredity 91: $448-455$

> Hämmerli A, Reusch TBH (2003b) Inbreeding depression influences genet size distribution in a marine angiosperm. Mol Ecol 12:619-629

Harper JL (1977) Population biology of plants. Academic Press, London

- Harrison PG (1993) Variations in demography of Zostera marina and $Z$. noltii on an intertidal gradient. Aquat Bot 45:63-77

Harwell MC, Orth RJ (2002) Long distance dispersal potential in a marine macrophyte. Ecology 83:3319-3330

Honnay O, Bossuyt B, Jacquemyn H, Shimono A, Uchiyama K (2008) Can a seed bank maintain the genetic variation in the above ground plant population? Oikos 117:1-5

Hootsmans MJM, Vermaat JE, Van Vierssen W (1987) Seedbank development, germination and early seedling survival of two seagrass species from the Netherlands: Zostera marina L. and Zostera noltii Hornem. Aquat Bot 28:275-285

> Inglis GJ (2000) Disturbance-related heterogeneity in the seed banks of a marine angiosperm. J Ecol 88:88-99

Jacobs RPWM, den Hartog C, Braster BF, Carriere FC (1981) Grazing of the seagrass Zostera noltii by birds at Terschelling (Dutch Wadden Sea). Aquat Bot 10:241-259

Jacobs RPWM, Noten TMPA, Claassen E (1983) Population and growth characteristics of the seagrass Zostera noltii Hornem in the Dutch Wadden Sea. Proc Int Symp Aquat Macrophytes, 18-23 Sep 1983, Nijmegen, p 95-100

Källström B, Nyqvist A, Åberg P, Bodin M, André C (2008) Seed rafting as a dispersal strategy for eelgrass (Zostera marina). Aquat Bot 88:148-153

Koch M, Huthmann M, Bernhardt KG (2003) Cardamine amara L. (Brassicaceae) in dynamic habitats: genetic composition and diversity of seed bank and established populations. Basic Appl Ecol 4:339-348

- Loques F, Caye G, Meinesz A (1988) Flowering and fruiting of Zostera noltii in Golfe Juan (French Mediterranean). Aquat Bot 32:341-352

Loques F, Caye G, Meinesz A (1990) Germination in the marine phanerogam Zostera noltii Hornemann at Golfe Juan, French Mediterranean. Aquat Bot 38:249-260

- Luckenbach MW, Orth RJ (1999) Effects of a deposit-feeding invertebrate on the entrapment of Zostera marina L. seeds. Aquat Bot 62:235-247

> Marbà N, Duarte CM (1998) Rhizome elongation and seagrass clonal growth. Mar Ecol Prog Ser 174:269-280

> Mayot N, Boudouresque CF, Leriche A (2005) Unexpected response of the seagrass Posidonia oceanica to a warmwater episode in the North Western Mediterranean Sea. C R Biol 328:291-296

McMillan C (1991) The longevity of seagrass seeds. Aquat Bot 40:195-198

Moore KA, Orth RJ, Nowak JF (1993) Environmental regulation of seed germination in Zostera marina L. (eelgrass) in Chesapeake Bay: effects of light, oxygen and sediment burial. Aquat Bot 45:79-91

Morris AB, Baucom RS, Cruzan MB (2002) Stratified analysis of the soil seed bank in the cedar glade endemic Astragalus bibullatus: evidence for historical changes in genetic structure. Am J Bot 89:29-36

Nacken M (1998) Einfluß der Sedimentverwühlungen von Ringelgänsen und Pfeifenten auf die Seegraswiesen und 
deren Makrofauna im Wattenmeer. Master thesis, University of Bremen

Olsen JL, Stam WT, Coyer JA, Reusch TBH and others (2004) North Atlantic phylogeography and large-scale population differentiation of the seagrass Zostera marina L. Mol Ecol 13:1923-1941

Orth RJ, Luckenbach M, Moore KA (1994) Seed dispersal in a marine macrophyte: implications for colonization and restoration. Ecology 75:1927-1939

Orth RJ, Harwell MC, Bailey EM, Bartholomew A and others (2000) A review of issues in seagrass seed dormancy and germination: implications for conservation and restoration. Mar Ecol Prog Ser 200:277-288

> Piry S, Alapetite A, Cornuet JM, Paetkau D, Baudouin L, Estoup A (2004) GENECLASS2: a software for genetic assignment and first-generation migrant detection. J Hered 95:536-539

Rannala B, Mountain JL (1997) Detecting immigration by using multilocus genotypes. Proc Natl Acad Sci USA 94: 9197-9201

Reise K, Kohlus J (2008) Seagrass recovery in the northern Wadden Sea? Helgol Mar Res 62:77-84

Reusch TBH (2001) New markers - old questions: population genetics of seagrasses. Mar Ecol Prog Ser 211:261-274

Reusch TBH (2002) Microsatellites reveal high population

Editorial responsibility: Kenneth Heck,

Dauphin Island, Alabama, USA connectivity in eelgrass (Zostera marina) in two contrasting coastal areas. Limnol Oceanogr 47:78-85

Reusch TBH (2003) Floral neighbourhoods in the sea: how floral density, opportunity for outcrossing and population fragmentation affect seed set in Zostera marina. J Ecol 91: 610-615

Reusch TBH (2006) Does disturbance enhance genotypic diversity in clonal organisms? A field test in the marine angiosperm Zostera marina. Mol Ecol 15:277-286

Reusch TBH, Hughes AR (2006) The emerging role of genetic diversity for ecosystem functioning: estuarine macrophytes as models. Estuaries Coasts 29:159-164

> Reusch TBH, Boström C, Stam WT, Olsen JL (1999) An ancient eelgrass clone in the Baltic. Mar Ecol Prog Ser 183: 301-304

Reusch TBH, Ehlers A, Hämmerli A, Worm B (2005) Ecosystem recovery after climatic extremes enhanced by genotypic diversity. Proc Natl Acad Sci USA 102:2826-2831

Thompson K, Bakker JP, Bekker RM (1997) The soil seed banks of north west Europe: methodology, density and longevity. Cambridge University Press, Cambridge

> Vermaat JE, Verhagen FCA (1996) Seasonal variation in the intertidal seagrass Zostera noltii Hornem.: coupling demographic and physiological patterns. Aquat Bot 52: 259-281

Submitted: June 25, 2008; Accepted: January 14, 2009 Proofs received from author(s): March 30, 2009 